features (Fig. 2), and cut to a depth of 600 feet across, and not down, the slope of a hillside for a length of eighty miles (pp. 12 and 43). This is explained by the action of an cverflow-stream from a lake held in between the icefront and the hills. Parts of several pre-Glacial streamcuts were utilised in its course.

The work of the Geologische Reichsanstalt of Vienna may conveniently be touched on in this article. In vol. Ivi. of the Jahrbuch of this institute (May, r9o6, p. 298) Dr. Stuchlik attributes a lateritic origin to the "bunte Mollasse " of the Oligocene of southern Bavaria, and urges that the red ferruginous material was washed down from tropical deltas into a shallow sea. B. Granigg's paper (p. 367 ) on the Ober-Mölltal in Carinthia contains some observations on the origin of serpentine; and it is instructive to note that the intrusive masses from which this rock has been produced have metamorphosed the adjacent mica-schist and quartzite in very various degrees. Contactalteration is at times hardly perceptible, a fact that may be taken into account in the discussion on the origin of the South African diamantiferous material. In the Verhandlungen of the Reichsanstalt, 1906, pp. 146-164, Dr. F. E. Suess gives a general account of the geology of the complicated district in the environs of Brünn. The

Thus in many cases they were deposited in gulfs running along the hollows of an ancient crystalline series. The author strips away these sediments, and seeks to trace the surface of a central Alpine land-mass denuded in prePalæozoic times. G. A. J. C.

\title{
OCEANOGRAPHICAL RESEARCH.
}

THE Prince of Monaco presided at the formal opening of the Scottish Oceanographical Laboratory at Edinburgh on the afternoon of Wednesday, January 16. A distinguished gathering of representative naturalists from the leading cities of Scotland took part in the ceremony. On the motion of the Lord Provost of Edinburgh, the Prince of Monaco was called upon to take the chair. A brief explanatory statement of the genesis and development of the laboratory and of the end aimed at was given by Mr. W. S. Bruce, the leader of the Scottish Antarctic Expedition and the founder and director of the laboratory. He showed how Scotland might be regarded as the cradle of oceanography, Edinburgh having been associated with the study of the oceans for a longer period than any other place in the world. The gathering together and arrangement of the material had been going on for years, and represented the work of eight scientific expeditions. In many respects it was an absolutely unique collection. The place it was now in was essentially a workshop for oceanography, and Mr. Bruce appealed to the people of Scotland to support this movement to place oceanographical research on a permanent footing. There were men able and willing to do the work if once the laboratory were properly established and affiliated to the great teaching institutions of the country.

In a short address the Prince of Monaco paid a high tribute to the admirable work which had been accomplished by $\mathrm{Mr}$. Bruce and his companions in the Antarctic seas. Their expedition had been probably the most fruitful of all the expeditions carried out about the same time, and yet by far the most economical. Seven other speakers, representing various interests, spoke as to the claims Mr. Bruce's new venture had on the people of Scot-

FIG. 2. The wall of the Shonkin Sag, a valley of glacial drainage in Montana.

sheet of the geological map described includes part of the ancient Bohemian plateau on the north-west, and part of the Cainozoic foothills of the Carpathians on the southeast. The picturesque and varied scenery on the old highway from Hungary to Prague is recalled to us in this lucid memoir. Brünn, little visited as it is, should clearly be an exceptional centre for the study of geology. The Ortler group furnishes W. Hammer (p. 174) with material for a discussion of Termier's views on Alpine structure. Dr. Kossmat (Jahrbuch der k.k. Reichsanstalt, 1906, p. 274) similarly finds himself involved with Termier and Lugeon in the "Gebiet zwischen dem Karst und dem Zuge der Julischen Alpen." A specialised congress on Alpine structure, with months of field-excursions, would be needed for the answering of all these questions; but even then the new views daily propounded would effectually overwhelm the answers. M. Vacek (Verhandlungen, 1906, p. 203) is allowed free scope for a highly controversial paper on the basin of Graz, in which he compares the "green beginner" in geology, who rushes into tectonics, to a stutterer delivering a public speech. The name of the specially "green" one is presently shouted across the barriers of this scarcely edifying tourney. The geological sections given are, of course, of considerable interest, and show a country rich in transgressions and unconformities. Vacek points out the need for considering the isolated masses of Palæozoic and Mesozoic sediments in relation to the geography of the times when they were laid down. land. Sir William Turner referred to the close connection which the University of Edinburgh had had with the Challenger expedition and with later expeditions of a like character. Dr. Dobbie said that the seals and birds which the Scottish Antarctic Expedition had presented to the Royal Scottish Museum were probably unsurpassed by any like collection in any museum of the kingdom, and that other museums had greatly benefited through the generosity of Mr. Bruce. Dr. Horne, as representing various scientific societies, made special reference to the geographical knowledge which had been gained by the staff of the Scotia, to the practical sympathy which the Scottish Geographical Society had taken in the expedition, and to the generous manner in which the Royal Society of Edinburgh, in spite of its straitened means, had undertaken the publication of the memoirs describing the results. Prof. Arthur Thomson, as representing other Scottish universities, directed particular attention to the character of the Oceanographical Laboratory as a place where a man could train himself for oceanographical work. Mr. Henry Coates, of the Perthshire Society of Natural Science, commented on the value of the collections in the laboratory being arranged as a regional museum. Dr. Rottenburg, of Glasgow, and Mr. Robert M'Vitie, of Edinburgh, expressed their sympathy with a project which seemed to be a natural consequence of the Antarctic Expedition, the success of which had rejoiced the hearts of the many who had been interested in it. 
The laboratory occupies a low one-storied building on the north side of the Surgeons' Hall. There are four rooms, the largest of which is filled with cases stored with specimens from the Arctic, while another contains specimens from the Antarctic. Each case is devoted to a particular group of animals, crustacea, fishes, molluscs, seaurchins, \&c., systematically arranged, with the memoirs and papers describing them placed on the lower shelf. One interesting case is arranged bathymetrically, the typical animals of different depths being placed on corresponding shelves. In the Antarctic room special cases are devoted to special regions, such as the Weddell Sea, Scotia Bay, \&c., or to different islands, the South Orkneys, Gough Island, the Falklands, and so on. One interesting specimen in the collection is a large granite boulder, icemarked, weighing 3 or 4 cwt., which had been dredged up from a depth of 177,5 fathoms in lat. $62^{\circ}$ Io $^{\prime} \mathrm{S}$. and long. $4 \mathrm{I}^{\circ} 20^{\prime}$ W. The whole collection, Arctic and Antarctic, represented the gatherings of the scientific work of five vessels, the Balaena, the Windward, the Blencathra, Princess Alice II., and the Scotia. Photographs of these and of interesting scenes during the Scotia's voyage decorated the walls. At the present time many of the specimens are in the hands of the naturalists who are working up the various groups, while the larger animals are for the most part distributed throughout Scotland in various museums. There are many duplicates which should prove useful in effecting exchanges with other similar institutions, and so gradually increase the value of the Edinburgh collection.

The inauguration of the Scottish Oceanographical Laboratory was the first of a series of public and semi-public functions at which the Prince of Monaco was the leading figure. On the evening of January 16 he was the principal guest at the dinner of the Royal Society Club. Lord Kelvin presided, and Prof. Geikie acted as vice-chairman. On Thursday, January 17, the Prince received the degree of Doctor of Laws from the University of Edinburgh. On the evening of the same day he delivered an address on the exploration of the high atmosphere before the Royal Scottish Geographical Society. Prof. Geikie, president of the society, occupied the chair, and introduced the Prince as one well known as an enthusiastic, devoted, and successful student of natural science. His investigations had been conducted on a scale which had only been rivalled by Government expeditions sent out by great nations. For at least twenty-five years he had traversed the ocean in search of knowledge. He had established a great oceanographical institute at Monaco, a weather bureau, and a museum, and last year he endowed at Paris an oceanographical institute at a cost of not less than $160,000 l$. The president then handed to the Prince the gold medal which the society had awarded him in recognition of his scientific work.

In the course of his address, the Prince said that in the last few years the improvements in the manufacture of steel had made it possible to fly kites at great heights, carrying self-registering apparatus. Also the india-rubber industry had enabled balloons, carrying self-registering apparatus, to be sent to altitudes hitherto inaccessible. Through the liberality of the German Emperor a great establishment had been set up at Lindenberg for the svstematic investigation of the upper-air meteorology. This was over the land. In 1904 the lecturer had become interested in the subiect, and he began to make plans for investigating the problem over the sea. To reach great heights it was necessary to attach to the line or wire a sories of kites at intervals, and if no layers of calm air were encountered a very great height could be reached. and the kite kept there by the vessel moving with a speed of not less than 7 metres per second. There were many difficulties on board ship due to complications of wind distributions in the different layers. After a season's work with kites in the Atlantic the Prince resolved to try the ballons-sondes. The method first adopted was to use two light india-rubber balloons filled with hvdrogen. The one carried the self-registering apparatus, while the other and more inflated balloon was attached to it, and aided the ascent to the required height. At this height the upper balloon burst, and the lower balloon with its instruments descended as a parachute, and hovered over the sea so long as the float at the end of the stray line touched the surface of the water. This could be seen at a distance of eight or ten miles. The bursting of the balloon was somewhat indefinite, and an improvement was subsequently effected by means of which the one balloon was released altogether at the desired height. This was done by means of a current from a small dry cell set in action when the pen of the barograph on the lower balloon tcuched a conductor set at the pressure corresponding to the desired height. Also by use of a formula taken in connection with the observed ascent of the system, the line of descent of the " ballon parachute" could be approximately calculated, and the ship steered for the place. By means of apparatus of this kind pressure and temperature curves had been brought back from a height of 7500 metres in latitude $78^{\circ} \cdot 55$. In the high latitudes the experiments had been greatly interfered with by fog. The drift of air in still higher regions had been studied by means of pilot balloons, which had been followed through the telescope of a theodolite to heights of nearly 30,000 metres. These indicated that in latitude $80^{\circ}$ north, at a height of about 13,600 metres, there were at times winds blowing with a velocity of 60 metres per second, or 130 miles per hour. The results of several cruises had shown that " if the principal States of the world were willing to diminish a little the expense of international quarrels by submitting them to the judgment of a tribunal less costly than that of war, and if they preserved more resources for the veritable interests of humanity, it would be possible with powerful means very soon to know the laws of meteorology, the key to which seemed to be found in the higher atmospheric regions.",

\section{UNIVERSITY AND EDUCATIONAL} INTELLIGENCE.

CAMBRIDGE.-The voting on the proposed reform of the mathematical tripos will take place on Friday and Saturday, February $I$ and 2.

The placet executive committee has issued a letter to non-resident members of the Senate pointing out that "the proposed scheme is supported by a large majority of the resident members of the Senate, a maiority which includes eight heads of houses, more than thirty professors, all the official university teachers of mathematics, and the whole mathematical staff of several of the larger colleges. Moreover, the principles of the reform have already been approved by the Senate. It is, however, impossible for the reform to be carried into effect unless it is supported by the votes of a large number of non-residents. . . The rejection of the proposed reform wculd be a great calamity for the future of the Cambridge School of Mathematics. Further, the precedent established by the reversal of a decision already made would be a serious menace to the practical working of the government of the University."

THE citizens of Montreal resolved at a meeting on January 16 to raise $200,000 l$. for an endowment fund for the McGill University. Mr. Robert Reford promised to contribute 10,00ol. Lord Grey presided, and Lord Strathcona was also present at the meeting.

A course of eight lectures on "Certain Fundamental Problems in Physiology Common to Animals and Plants," to be given at University College, London, by Dr. W. M. Bayliss, F.R.S., commenced on Wednesday, January 23. The lectures are open to all students of the University of London.

Mr. G. P. Darnell Smith has been appointed assistant director of technical education and manual training to the Board of Education, Auckland, New Zealand. Mr. Darnell Smith has been on the staff of the Merchant Venturers' Technical College, Bristol, since September, 1892 , and some time ago he was promoted to the post of assistant professor of chemistry in the college.

The Duke of Northumberland on January 17 opened the new Royal Grammar School at Newcastle-upon-Tyne, which has been built by the governors at a cost of $60,000 l$. to take the place of an older building. In his inaugural address the Duke of Northumberland said, with regard to recent elementary education, we have probably over- 